\title{
Further evidence for the presence of subepithelial nerve cells in the rat ileum-an immunohistochemical study
}

\author{
A. DAHLSTRÖM, ${ }^{1}$ B. NEWSON, ${ }^{2}$ S. NAITO, ${ }^{3}$ T. UEDA $^{3}$ and H. AHLMAN ${ }^{4}$ \\ 'Institute of Neurobiology, and ${ }^{4}$ Department of Surgery I, University of Göteborg, Sweden, ${ }^{2}$ Department of Surgery, \\ Abraham Lincoln School of Medicine, University of Illinois, Chicago, and ${ }^{3}$ Mental Health Research Institute \\ and Department of Pharmacology, University of Michigan, Ann Arbor, USA
}

\begin{abstract}
DAHLSTRÖM, A., NEWSON, B., NAITO, S., UEDA, T. \& AHLMAN, H.: Further evidence for the presence of subepithelial nerve cells in the rat-ileum-an immunohistochemical study. Acta Physiol Scand 1984, 120:1-5. Received 12 Nov. 1982. Accepted 13 June 1983. ISSN 0001-6772. Institute of Neurobiology, and Department of Surgery I, University of Göteborg, Sweden, Department of Surgery, Abraham Lincoln School of Medicine, University of Illinois, Chicago, and Mental Health Research Institute and Department of Pharmacology, University of Michigan, Ann Arbor, USA.
\end{abstract}

Earlier we observed electronmicroscopically an unidentified but neuron-like subepithelial cell in the crypts of the rat ileum. We have now studied some immunocytochemical characteristics of similar cells in the fluorescence microscope by indirect immunofluorescence. Three markers for neuronal tissues were used: 1) Monoclonal Thy-1-antibodies, demonstrated previously to recognize surface antigens of thymus-derived cells and nervous tissue; 2) Tetatus toxin, which binds to the $G_{T 1}$ ganglioside receptor of nerve cells, and to some other neuronal receptor; and 3) Anti-Protein I-IgG, which is monospecific for Protein I located in synaptic vesicle membranes. The various antisera used for secondary incubations all reacted with leucocytes and other connective tissue cells in the villous cores. When the specific primary antisera of Thy- 1 and Protein I, and tetanus toxin, were included, a small number of spindle-shaped cells with two processes, extending just beneath the basal lamina of the epithelium, was observed. These cells had a similar location and appearance as the neuron-like cells observed electronmicroscopically and may be identical with these cells. These results give further evidence that cells with neuron-like characteristics are present in the mucous layer of the small intestine.

Key words: Subepithelial nerve cells, tetanus toxin, Thy-1, Protein I, rat ileum

Earlier we have reported the electronmicroscopical observation of an unidentified, but neuron-like, cell in the rat ileal mucosa (Newson et al. 1979, 1982). This type of cell has not, to our knowledge, been described earlier. It is rather small, elongated, and located just outside the basal lamina of the mucosal epithelium in the crypts. The nucleus is rather sparse in chromatin, but the nucleolus is prominent. The cytoplasm is light but with abundant ribosomes and $\mathrm{gER}$, and extend into the two major processes observed (see Newson et al. 1979, 1982). A few electron-dense large organelles are present. Many nerve processes and terminals are found close to the cell, and occasional synapse-like membrane-specializations have been observed.
In order to obtain further evidence for the possible neuronal character of this type of cell, the present cytochemical study was undertaken. We have attempted to make use of three markers considered to be relatively specific for neuronal tissues, Thy-1antibodies, tetanus toxin (TeTox), and Protein Iantibodies.

\section{MATERIAL AND METHODS}

Male Sprague-Dawley rats $(200 \mathrm{~g})$ were used. The rats were anesthesized with Nembuthal $(50 \mathrm{mg} / \mathrm{kg}$ i.p.) and perfusion-fixed with $100 \mathrm{ml}$ of bodywarm Ringer solution, followed by $250 \mathrm{ml}$ of ice-cold $4 \%$ formaldehyde in PBS, $\mathrm{pH}$ 7.3. Parts of the ileum (where the original observation was made) were dissected out, postfixed in the same 


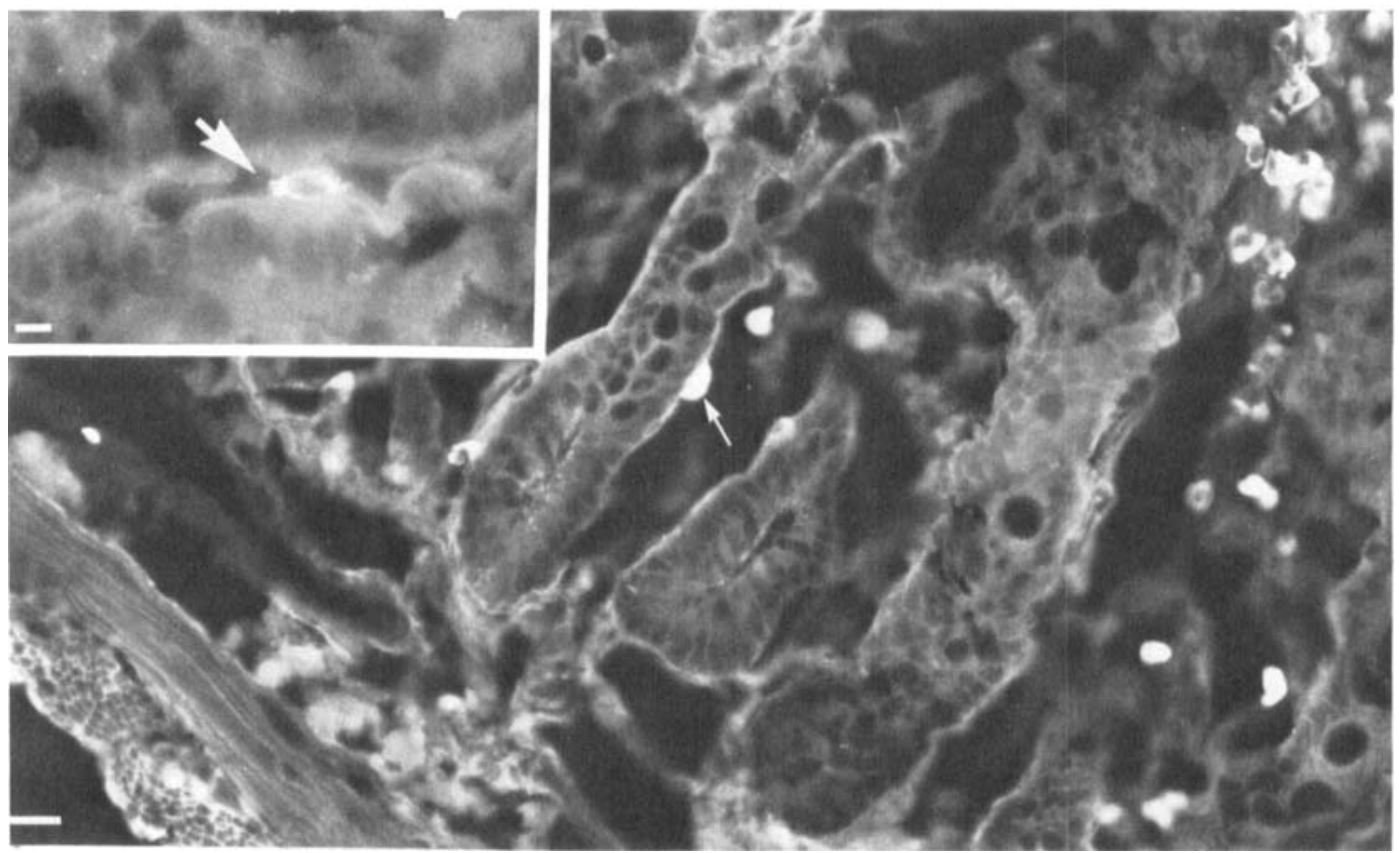

Fig. I. Cryostat section of rat ileum, incubated with monoclonal antibodies to Thy-1 $(1: 200)$ and as second antiserum rabbit anti-mouse IgG-FITC (1:10). Some labelled leucocyte-like cells can be seen in the villous core top right. In the crypts, only few such cells are seen, but they are unspecifically stained and appear when only the secondary incubation was made. When Thy-1 antiserum was added small bipolar cells were seen close to the crypt epithelium (arrow). Fluorescence micrograph $\times 120$. Inlet shows higher magnification of another Thy-1-positive cell $(\times 250)$.

fixative for $3 \mathrm{~h}$, rinsed for $12 \mathrm{~h}$ in PBS with $5 \%$ sucrose for cryoprotection. Cryostat sections $(10 \mu \mathrm{m})$ were placed on gelatin-coated slides and stored at $-20^{\circ} \mathrm{C}$ until incubated.

The following substances were used for incubation: 1 . Monoclonal antibodies against Thy-1 antigen. This antigen is a surface antigen, considered to be specific for thymus-derived cells and for neuronal tissues (cf. Barclay \& Hydén 1978). It was used in dilutions of $1: 200$. As second antibody rabbit antimouse IgG, labelled with FITC, was used in dilution $1: 10$. 2. Crude TeTox $(260$ $\mathrm{IU} / \mathrm{ml}$ ) was used in dilution $1: 100$ or $1: 200$. The bound toxin was localized by a second incubation with homo anti-tetanus serum in dilution $1: 200$, and FITC-conjugated rabbit anti-homo-IgG was then used to localize the bound homo IgG. As controls, series of incubations where TeTox and/or human anti-TeTox serum were excluded were carried out. 3. The IgG fraction of Anti-Protein Iantiserum, produced in rabbits, was purified by affinity chromatography, as described earlier (Naito \& Ueda 1981), and used in dilutions of $1: 100$ or $1: 200$. As second antibody FITC-conjugated swine antirabbit IgG, dilution $1: 10$, was used.

TeTox and homoanti-tetanus serum were obtained from SBL (Stockholm, Sweden). All other antisera, except for anti-Protein I (see above) were purchased from Dakopatts (Copenhagen, Denmark). Incubations with the FITC-labelled antisera were carried out for $1 \mathrm{~h}$ at $37^{\circ} \mathrm{C}$, while all other incubations were carried out at $+4^{\circ} \mathrm{C}$ overnight.

\section{RESULTS}

The gastrointestinal mucosa is a tissue which contains many cell types which bind immunoglobulins unspecifically, due to the electrical changes of their cell membranes, or to the presence of Fc-components on their surface (cf. Brandtzaeg 1973, 1974). It was therefore of utmost importance to compare results with the "specific markers" with the picture obtained when these markers were excluded.

Anti Thy-1. This monoclonal antibody is directed towards the Thy-1 antigen which is considered to be present on the surface of thymusderived cells and of neurons (cf. Barclay \& Hydén 1978). The cell types visualized with this marker were 1) a large number of connective tissue cells in the core of the villi, and 2) a few small elongated cells just beneath the basal lamina of the crypt epithelium (Fig. 1). These cells covered approximately the base of 2-3 intestinocytes and had the same appearance as the cells observed in the electron microscope earlier. Also fibroblasts may have this appearance, however, and Broches et al. (1977) have observed that rat fibroblasts may be Thy-1-positive 

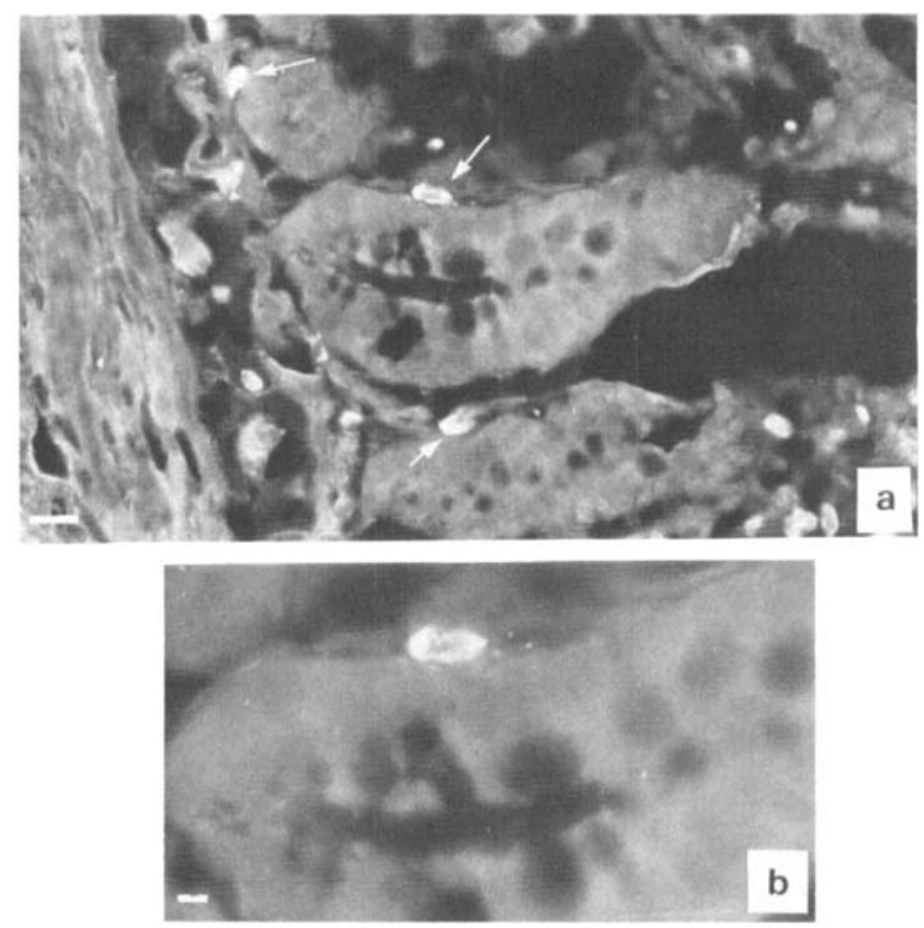

Fig. 2. (a) Cryostat section of rat ileum incubated with tetanus toxin $(2.6 \mathrm{IU} / \mathrm{ml})$, then with homo anti-tetanus antiserum $(1: 200)$ and finally with rabbit anti-homo-IgG-FITC. Three spindle-shaped cells with specific fluorescence (they were not observed if tetanus toxin was excluded) are observed (arrows) in the crypts, close to the base of the epithelium. (b) Higher magnification of the middle cell, showing a more homogenous fluorescence near the poles. The high background fluorescence is mainly due to the incubation with homo anti-TeTox. Magnifications $120 \times$ and $250 \times$, respectively.

in cultures. On the other hand fibroblasts are more numerous than the cells of interest in this study, and therefore it seems highly unlikely that the rather few cells observed are fibroblasts.

Tetanus toxin. Incubation with secondary antisera only always resulted in a varying number of brightly fluorescent cells in the connective tissue, especially in the stroma of the villi. The homo antitetanus serum gave the highest background fluorescence and many leucocytes (with segmented nuclei), demonstrated a strong fluorescence. The difference between the control sections (incubated with the two antisera only) and the TeTox incubated sections was the presence of a few small flat, spindle-shaped cells, labelled by the toxin. These cells were observed immediately beneath the basal lamina, and corresponded in appearance to the cells observed electronmicroscopically (Fig. $2 a$ ). These cells were mainly located in the crypts, and were only occasionally observed in the villi, where a great abundance of the leucocyte-like cells was found (Fig. $2 b$ ). The sera did not contain Triton X100 , because it is known that TeTox binds to a surface ganglioside $\left(\mathrm{G}_{\mathrm{TI}}\right)$ receptor (cf. van Heyningen 1974, Zimmermann \& Piffaretti 1977). Thus, the toxin or the antisera did not need to traverse any membranes. The fluorescence picture of these small, flat cells was that the entire surface appeared to be covered with label. The toxin should also have labelled nerve terminals, since these are rich in $\mathrm{G}_{\mathrm{Tl}}$ receptors (cf. Stoeckel et al. 1977). However, only rarely labelled nerve fibres were detected.

Anti-Protein I IgG. Protein I is a neuron specific, synapse specific antigen, which serves as an endogenous substrate for cAMP-activated and calciumactivated protein kinases (Ueda et al. 1973, Krueger et al. 1977). It is highly localized in the synaptic region, particularly on synaptic vesicles 


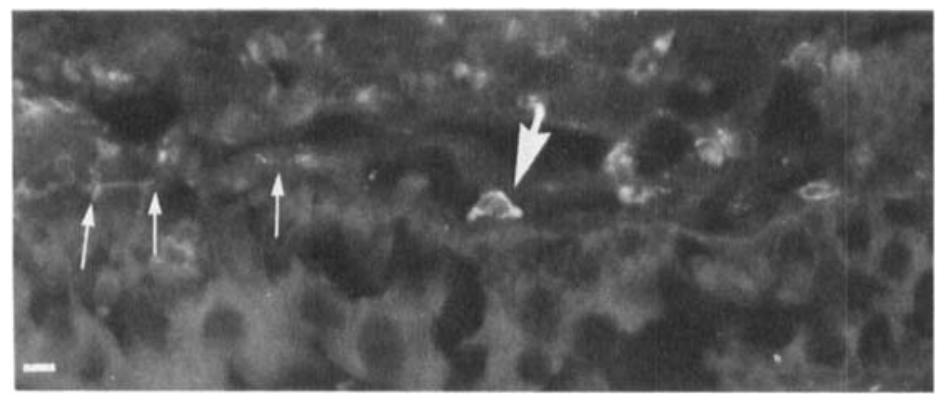

Fig. 3. Crypt and part of a villus in cryostat-section of rat ileum, incubated with antiprotein I-IgG $(1: 200)$ and swine antirabbit IgG-FITC $(1: 10)$. Many leucocytes with weak yellowish autofluorescence are seen, and a few delicate specifically labelled nerve terminals $(\rightarrow)$. In the center of the picture a spindle-shaped cell is observed close to the base of the epithelium. ( $\triangleright$ ). Magnification $120 \times$.

(Bloom et al. 1979, DeCamilli et al. 1979, Ueda et al. 1979). It was used in this study because of its specificity for nerves. Many varicose nerve-fibres were observed, using the antiserum (Fig. 3). In addition to nerve fibres, we also observed a few rather weakly, but specifically fluorescent, elongated cells under the crypt epithelium. Only few leucocytes were unspecifically labelled by the swine antirabbit-FITC serum alone. The Protein I-positive cells had an appearance similar to that of the cells seen with the two other antisera. The distribution of fluorescence over the cells was not homogenous. A lot of small patches, densely distributed over the cell membrane, appeared to constitute the fluorescence picture. One may speculate, if these patches represent efferent boutons, filled with synaptic vesicles. Immunocytochemistry at the ultrastructural level will elucidate this question.

\section{DISCUSSION}

The three markers used in this study are considered to label nervous tissues in different ways. TeTox binds to $G_{T l}$, gangliosides of the nerve membrane, but also to some other, as yet unidentified neuronal receptors (cf. Zimmerman \& Piffaretti 1977, Stoeckel et al. 1977). In living tissue TeTox is internalized after binding to the cell membrane, and can then be transported intraneuronally. In fixed tissues the toxin stays bound to the membrane.

The Thy-1-antigen has been demonstrated to be located to thymusderived cells and to nervous tissue (cf. Barclay \& Hydén 1978) and could therefore be expected to recognize the small flat neuron-like cells earlier observed electronmicroscopically, if these were neuronal in nature. However, this antiserum would label the cells also if they were flat thymocytes, which would be quite feasable in this particular location, since the gut is rich in cells of the immune system.

The third marker, the Protein I-antiserum, has been shown to label synaptic nerve endings and more specifically synaptic vesicles generally (Bloom et al. 1979). Positivity for anti-Protein I would therefore indicate the presence of synaptic vesicles or granules in or on the surface of the cell. The Protein I positive cells observed here had an appearance similar to that of the Thy-1 and TeTox positive cells, located just beneath the basal lamina of the epithelium. The cells observed in the electronmicroscope had rather few organelles (Newson et al. 1979, 1982) and definitely too few synaptic vesicle-like structures to allow for the medium fluorescence intensity observed in this study. However, the Protein I-like antigen observed could be located to the gER or to the Golgi, under synthesis or packing for export out into the processes. Alternatively, synaptic boutons ending on this cell could give the observed pattern of fluorescence.

The three markers used all labelled the same type of flat small subepithelial cell similar to the one observed in the electron microscope. This gives support to our suggestion that this cell may be a subepithelial nerve cell, but cannot be regarded conclusive evidence. Immunocytochemical studies at the ultrastructural level will yield further information. 
Supported by grants from the Swedish MRC (14X-2207. 17X-5220), by the Veterans Administration West Side Hospital, by the M. Bergvall Foundation, H. \& G. Jeansson's Foundation and by W. \& M. Lundgren's Foundation. We thank A.-M. Ahlbom, SBL, Stockholm, for a generous supply of tetanus toxin. The technical assistance of Kerstin Lundmark is gratefully acknowledged.

\section{REFERENCES}

BARCLAY, A. N. \& HYDÉN, H. 1978. Localization of the Thy-1-antigen in rat brain and spinal cord by immunofluorescence. J Neurochem 31: 1375-1391.

BLOOM, F. E., UEDA. T., BATTENBERG, E. \& GREENGARD, P. 1979. Immunocytochemical localization, in synapses, of protein I, an endogenous substrate for protein kinases in mammalian brain. Proc Natl Acad Sci USA 76: 5982-5986.

BRANDTZAEG, P. 1973. Conjugates of immunoglobulin $G$ with different fluorochromes. II. Specific and nonspecific binding properties. Scand J Immunol 2: 333-348.

BRANDTZAEG, P. 1974. Mucosal and glandular distribution of immunoglobulin components. Immunohistochemistry with a cold ethanol-fixation technique. Immunology 26: 1101-1114.

BROCHES, J. P., FIELDS, K. L. \& RAFF, M. C. 1977. A surface antigenic marker for rat Schwann cells. Nature (Lond.) 266: 364-366.

DECAMILLI, P., UEDA, T., BLOOM, F. E., BATTENBERG, E. \& GREENGARD, P. 1979. Widespread distribution of protein $I$ in the central and peripheral nervous systems. Proc Natl Acad Sci USA 76: 5977-5981.

VAN HEYNINGEN, W. E. 1974. Gangliosides as membrane receptors for tetanus toxin, cholera toxin and serotonin. Nature (Lond.) 249:415-417.
KREUGER, B. K., FORN, J. \& GREENGARD, P. 1977. Depolarization-induced phosphorylation of specific proteins, mediated by calcium ion influx, in rat brain synaptosomes. J Biol Chem 252: 2764-2773.

NAITO, S. \& UEDA, T. 1981. Affinity-purified antiprotein I antibody. J Biol Chem 256: 10657-10663.

NEWSON, B., AHLMAN, H., DAHLSTRÖM, A. \& NYHUS, L. M. 1982. Ultrastructural observations in the rat ileal mucosa of possible epithelial "taste-cells" and submucosal sensory neurons. Acta Physiol Scand 114: 161-164.

NEWSON, B., AHLMAN, H., DAHLSTRÖM, A., DAS GUPTA, T. K. \& NYHUS, L. M. 1979. Are there sensory neurons in the mucosa of the mammalian gut? Acta Physiol Scand 105: 521-523.

STOECKEL, K., SCHWAB, M. \& THOENEN, H. 1977. Role of gangliosides in the uptake and retrograde axonal transport of cholera and tetanus toxin as compared to nerve growth factor and wheat germ agglutinin. Brain Research 132: 273-285.

UEDA, T., MAENO, H. \& GREENGARD, P. 1973. Regulation of endogenous phosphorylation of specific proteins in synaptic membrane fractions from rat brain by adenosine $3^{\prime}: 5^{\prime}$-monophosphate. J Biol Chem 248: 8295-8305.

UEDA, T. GREENGARD, P., BERZINS, K., COHEN, R. S., BLOMBERG, F., GRAB, D. J. \& SIEKEVITZ, P. 1979. Subcellular distribution in cerebral cortex of two proteins phosphorylated by a cAMPdependent protein kinase. J Cell Biol 83: 308-319.

ZIMMERMAN, J. M. \& PIFFARETTI, J. Cl. 1977. Interaction of tetanus toxin and toxoid with cultured neuroblastoma cells: analysis by immunofluorescence. Naunyn-Schmiedebergs Arch Exp Path Pharmak 296: 271-277. 